\title{
IMPACT OF STRATEGIC LEADERSHIP ON STRATEGIC COMPETITIVE ADVANTAGE THROUGH STRATEGIC THINKING AND STRATEGIC PLANNING: A BI-MEDITATIONAL RESEARCH
}

\author{
Mohammad HUNITIE \\ Department of Public Administration, Faculty of Economics and Administration, \\ King Abdulaziz University, Jeddah, Saudi Arabia \\ E-mail:mohammadhunitie@live.com
}

Received 21 September 2018; accepted 11 November 2018

\begin{abstract}
Confusion between strategic planning and strategic thinking in the context of strategic leadership and its effect on competitive advantage was the foremost rationale for this study to come into view. Thereby, the aim of this study was to examine the role of two mediating variables, i.e., strategic planning and strategic thinking in the impact of strategic leadership on competitive advantage. Scoping health care sector in Jordan resulted in three public hospitals agreed to participate in the study. Data were gathered using a questionnaire developed on the basis of literature review. A total of 1000 questionnaires were administered to hospitals. A total 521 questionnaires were returned with a response rate of $52.1 \%$. The results pinpointed that strategic leadership significantly predicted strategic planning, strategic thinking and competitive advantage. the results also revealed that strategic planning and strategic thinking significantly and positively related to competitive advantage. accordingly, it was approved that strategic planning and strategic thinking mediated the effect of strategic leadership on competitive advantage. Despite that the influence of strategic thinking on competitive advantage was greater than the influence of strategic planning on competitive advantage. The study hold the perspective that both strategic planning and strategic thinking were essential in the context of strategic leadership, since strategies are developed by strategic thinking and operationalized via strategic planning.
\end{abstract}

Keywords: strategic leadership, strategic thinking, strategic planning, competitive advantage.

JEL Classification: M10.

\section{Introduction}

In "The Fall and Rise of Strategic Planning", Henry Mintzberg (1994) argued that "Strategic planning isn't strategic thinking" (p. 107). On the basis of this statement and in line with the significance of strategic leadership for organization to develop competitive advantage (Mahdi and Almsafir 2014, du Plessis et al. 2016), this study examined a model consisted of four constructs: strategic leadership, strategic thinking, strategic planning and competitive advantage. strategic leaders in general have specific roles under their main target which is to steer the organization to its desirable end of competitive advantage (Hughes and Beatty, 2011). In doing so, strategic leaders should possess core capabilities in relation to their strategic orientation, strategic implementation, strategic alignment, and development of core competencies (Davies 2004). Research on strategic leadership highlighted numerous factors that have an effect on this process such strategic flexibility which is the ability to scan the external environment and to deal with environmental changes (Hitt et al. 1998).

In terms of the relationship between strategic leadership and competitive advantage, one of the most well documented relationships in the literature is the relationship between these two constructs. Rush (2011) stated that "strategic leadership enhances an organization's sustainable competitive advantage through not only its strategy but also its vision, values, culture, climate, leadership, structure, and systems" (p. 13). According to Hoskisson et al. (2012), a major source

Copyright @ 2018 The Authors. Published by VGTU Press.

This is an Open Access article distributed under the terms of the Creative Commons Attribution License (http://creativecommons.org/licenses/by/4.0/), which permits unrestricted use, distribution, and reproduction in any medium, provided the original author and source are credited.. 
of an organization's competitive advantage is strategy formulation and execution.

On the other hand, there was a debate among researchers about the relationship between strategic planning and strategic thinking. In this regard, Heracleous (1998) mentioned that there are three views regarding the relationship between these two variables. The first view is that strategic planning and strategic thinking are important in the context of strategic leadership. The second view is that strategic thinking is an implicit issue within strategic planning. The third view is that strategic thinking is more important than strategic planning as it is the origin of strategy production. Mintzberg (1994) hold the first view and outlined strategic planning in terms of analysis organizational goals and strategic thinking in terms of synthesis of creativity.

Despite the importance of strategic leadership, competitive advantage, planning and strategic thinking for organizations, the studies that dealt with the intermediate role of strategic planning and strategic thinking in relation between strategic leadership are not available, according to the researcher's best knowledge. Have its purpose in the above literature, this study aimed at examining the effect of strategic leadership on competitive advantage through strategic planning and strategic thinking. Beyond its close purpose, the study sought to determine the mediation role of strategic planning and strategic thinking in the effect of strategic leadership on competitive advantage. in fact, this study contributes to the body of literature through the identification of strategic planning and strategic thinking in such an effect.

\section{Literature review and hypotheses development}

\section{Strategic leadership prototype}

In the new century, the landscape turned very competitive, due to trends of technology, democratization and globalization (Halal and Taylor, 1999), putting strain on the very boundaries and structures of organizations. The organizational environment became very complex, drew more attention. This is affected to the leadership roles from traditional to strategic roles. The results of The Center for Creative Leaders CCL study support this, found that the challenges facing leaders today, so complex, so we need a new view of the leadership. Podolny et al. (2005) observed the leadership has been subject to criticism and marginalization by the dominant organizational paradigms and perspectives.

Two key differences between leadership and strategic leadership were suggested by Hambrick and Pettigrew (2001, as cited in Vera and Crossan 2004). According to them, leadership is related to all leaders in the organization regardless of the management level, whereas strategic leadership refers to leaders at the top level of the organization.
Therefore, leaders at the top level of the organization have different roles of those who are in the middle level (Vera and Crossan 2004). Examples of strategic leaders' roles named by Boal and Hooijberg (2000) include strategic decisionmaking, development of organization's core competencies, development of organizational structure, establishment and communication of organization's mission, and development of new leaders. Davies (2004) identified five core abilities a strategic leader, which were strategic orientation, strategy implementation, strategic alignment, determination of strategic interventions, and development of strategic competencies. Due to their importance in any organization seeks to cope speedily changes, strategic leaders are faced with different challenges such as making wisdom decisions (Avolio 2007).

Strategic leadership was conceptualized in terms of many dimensions in the literature. Davies and Davies (2004) identified two groups of strategic leader abilities: abilities required to achieve the organizational activities as well as personal abilities. Organizational activities related abilities were rephrased as key dimensions of strategic leadership in the current study. These dimensions are strategic orientation, strategic execution, strategic alignment, and strategic competencies development. In a study by Grawe et al. (2009), strategic orientation was divided into three kinds of orientations: customer orientation (knowledge of customers and how to serve them), competitor orientation (knowledge of key competitors and how to cope with their related challenges) and cost orientation (knowledge of products or services costs and how to save costs). Strategic execution or implementation was described by Bourgeois and Brodwin (1984) as a process of using organizational structure tactics, incentives, control systems to help the implementation of strategies. For Ahriz et al. (2018), strategic alignment refers to coherence of organizational strategy with internal and external organizational function. Gratton and Truss (2003) put in place a human resource strategy with three dimensions of alignment: vertical alignment (alignment between strategy and organizational goals), horizontal alignment (alignment between $\mathrm{HR}$ functions and other organizational functions) and strategy implementation (managers behaviors and employees experiences). Hitt and Duane (2002) and Mahdi and Almsafir (2014) used human capital and social capital as dimensions of strategic leadership.

In line with these perspectives of strategic leadership, an associated concept, i.e., strategic flexibility, was emerged to describe the organization ability to get through external changes in the surrounded environment. Hitt et al. (1998) defined strategic flexibility as a capability of an organization that make to show a quick response to changeable circumstances so as to be able to establish its own competitive advantage position and keep going on. Shimizu and Hitt (2004) viewed this concept as organization's ability to scan 
its external environment for changes and to respond to these changes in a rapid manner through providing required resources. Zahra et al. (2008) underlined the importance of strategic flexibility for organizations. They regarded this ability as a mean that help the organization to effectively utilize its resources. Johnson et al. (2003) presented three aspects of flexibility, which were operational flexibility, tactical flexibility and strategic flexibility. Their conceptualization of these aspects' views operational flexibility as a short-term ability to deal with problems of daily operations. The author class operational flexibility as an ability to approach changes in product mix or product design. Finally, they supposed strategic flexibility to be a capability of the organization to handle changes in the environment. Nadkarni and Herrmann (2010) defined strategic flexibility as a quick adaptation of an organization to environmental changes. Table 1 showed dimensions of strategic leadership used in this study.

Competitive advantage has been defined as organization's ability to gain, at least, the economic gains achieved by other competitive organizations in the same business (Hili et al. 2017). Building on resource-based model, Lado et al. (1992) evaluated competitive advantage as an exclusive competency by which the organization gains a competitive edge over other competitors. Mahdi and Almsafir (2014) investigated the role of strategic leadership in the academic environment using a sample of academic leaders and revealed that strategic leadership significantly and positively predicted organization's sustainable competitive advantage. Zhou et al. (2009) cited a positive impact of customer orientation, as a dimension of strategic leadership used in

Table 1. Dimensions of strategic leadership used in this study

\begin{tabular}{|c|l|l|}
\hline No. & \multicolumn{1}{|c|}{ Dimensions } & \multicolumn{1}{|c|}{ Sources } \\
\hline 1. & $\begin{array}{l}\text { Strategic orientation: } \\
\text { Customer orientation } \\
\text { Competitor orientation } \\
\text { Cost orientation }\end{array}$ & $\begin{array}{l}\text { Davies (2004), } \\
\text { Davies and Davies (2004), } \\
\text { Grawe et al. (2009) }\end{array}$ \\
\hline 2. & $\begin{array}{l}\text { Strategic execution: } \\
\text { Using organizational } \\
\text { structure tactics } \\
\text { Incentives system } \\
\text { Control systems }\end{array}$ & $\begin{array}{l}\text { Bourgeois and Brodwin } \\
\text { (1984), } \\
\text { Davies and Davies (2004) }\end{array}$ \\
\hline 3. & $\begin{array}{l}\text { Strategic alignment: } \\
\text { Vertical alignment } \\
\text { Horizontal alignment }\end{array}$ & $\begin{array}{l}\text { Gratton and Truss (2003), } \\
\text { Davies and Davies (2004), } \\
\text { Ahriz et al. (2018) }\end{array}$ \\
\hline 6. & $\begin{array}{l}\text { Strategic flexibility: } \\
\text { External environment } \\
\text { scan } \\
\text { Rapid response to changes }\end{array}$ & $\begin{array}{l}\text { Hitt et al. (1998), } \\
\text { Boal and Hooijberg (2000), } \\
\text { Johnson et al. (2003), } \\
\text { Shimizu and Hitt (2004), } \\
\text { Zahra et al. (2008), } \\
\text { Nadkarni and Herrmann } \\
\text { (2010) }\end{array}$ \\
\hline 7. & $\begin{array}{l}\text { Intangible capital: } \\
\text { Human capital } \\
\text { Social capital }\end{array}$ & $\begin{array}{l}\text { Hitt and Duane (2002), } \\
\text { Mahdi and Almsafir (2014) }\end{array}$ \\
\hline
\end{tabular}

the present study, on competitive advantage. According to Combe and Greenley (2004), strategic flexibility provides organizations with a particular competitive advantage because of the abilities of strategic flexibility that enable the organization to treat environmental changes. In fact, competitive advantage related capabilities cannot be imitated by competitors. On the other hand, Hili et al. (2017) found that leadership has no significant impact on competitive advantage.

Logically stated, strategic planning is one of the most processes rooted in strategic leadership (Deeboonmee and Ariratana 2014). Strategic planning process is the first phase of strategic management and establishes the foundation for the other phases (Julian 2013). Strategic planning is not limited to top management, but a function of all managers in the organizations (Steiner 2010). Strategic planning was defined as an interactive process between managers, leaders and followers with the aim of creating common goals. Strategic planning as a basic capability is very important to leader's success (Ebener and Smith 2015). As a cognitive ability, strategic thinking was regarded as essential for leaders. This ability refers to prediction of organization's future and take actions that allow to achieve the proposed future (Betz 2016). Based on the above-mentioned literature, the following hypotheses were suggested:

H1: strategic leadership shows a significant effect on competitive advantage.

H2: strategic leadership is significantly related to strategic planning.

H3: strategic leadership is significantly related to strategic thinking.

H4: strategic planning shows a significant effect on competitive advantage.

H5: strategic thinking shows a significant effect on competitive advantage.

\section{Methodology}

\subsection{Sample}

There are 32 public hospitals with a capacity of 5177 beds in Jordan. The entire scope of this study consisted of three public hospitals in Jordan. Three public hospitals were selected in Jordan, North, Central and South. As the largest hospital in the Central, 500 questionnaires were distributed and 250 questionnaires were distributed in each hospital in the north and south. The collected data were used to evaluate all constructs in this study. A total of 1000 questionnaires was administered to leaders in hospitals. This number of questionnaires have been distributed to ensure that a large number of questionnaires are retrieved to represent the views of the study population. A total 521 questionnaires were returned with a response rate of $52.1 \%$ from three public hospitals. 


\subsection{Measures}

Strategic leadership was measured using 22 items adapted from previous studies (Boal and Hooijberg 2000, Hitt and Duane 2002, Gratton and Truss 2003, Johnson et al. 2003, Vera and Crossan 2004, Combe and Greenley 2004, Shimizu and Hitt 2004, Davies 2004, Davies and Davies 2004; Zahra et al. 2008, Nadkarni and Herrmann 2010, Grawe et al. 2009, Mahdi and Almsafir 2014, Deeboonmee and Ariratana 2014, Ebener and Smith 2015, Betz 2016, Hili et al. 2017, Ahriz et al. 2018) strategic planning was assessed via 6 items based on Boyd and Reuning-Elliott (1998), strategic thinking (6 items) and competitive advantage (6 items) were measured based on measurements and scales found in previous studies Factors and indicators applied in this study to measure strategic leadership along with strategic planning, strategic thinking and competitive advantage is shown in Table 2.

\subsection{Study model}

The conceptual model of this study is shown in Figure 1. It consists of four latent variables (strategic leadership,

Table 2. Factors, indicators and number of items applied to measure variables

\begin{tabular}{|c|c|c|c|}
\hline Factors & Indicators & Sub-indicators & $\begin{array}{l}\text { No. of } \\
\text { Items }\end{array}$ \\
\hline \multirow{11}{*}{$\begin{array}{l}\text { Strategic } \\
\text { leadership }\end{array}$} & \multirow{3}{*}{$\begin{array}{l}\text { Strategic } \\
\text { orientation }\end{array}$} & $\begin{array}{l}\text { customer orien- } \\
\text { tation }\end{array}$ & 2 \\
\hline & & $\begin{array}{l}\text { competitor } \\
\text { orientation }\end{array}$ & 2 \\
\hline & & cost orientation & 2 \\
\hline & \multirow{2}{*}{ Strategic execution } & $\begin{array}{l}\text { organizational } \\
\text { structure }\end{array}$ & 2 \\
\hline & & $\begin{array}{l}\text { incentives } \\
\text { system }\end{array}$ & 2 \\
\hline & \multirow{2}{*}{$\begin{array}{l}\text { Strategic } \\
\text { alignment }\end{array}$} & $\begin{array}{l}\text { vertical align- } \\
\text { ment }\end{array}$ & 2 \\
\hline & & $\begin{array}{l}\text { horizontal } \\
\text { alignment }\end{array}$ & 2 \\
\hline & \multirow{2}{*}{ Strategic flexibility } & $\begin{array}{l}\text { external envi- } \\
\text { ronment scan }\end{array}$ & 2 \\
\hline & & $\begin{array}{l}\text { rapid response } \\
\text { to changes }\end{array}$ & 2 \\
\hline & \multirow{2}{*}{ Intangible capital } & human capital & 2 \\
\hline & & social capital & 2 \\
\hline $\begin{array}{l}\text { Strategic } \\
\text { planning }\end{array}$ & One-factor & & 6 \\
\hline $\begin{array}{l}\text { Strategic } \\
\text { thinking }\end{array}$ & One-factor & & 6 \\
\hline \multirow[t]{2}{*}{$\begin{array}{l}\text { Competitive } \\
\text { advantage }\end{array}$} & One-factor & & 6 \\
\hline & & & 40 \\
\hline
\end{tabular}

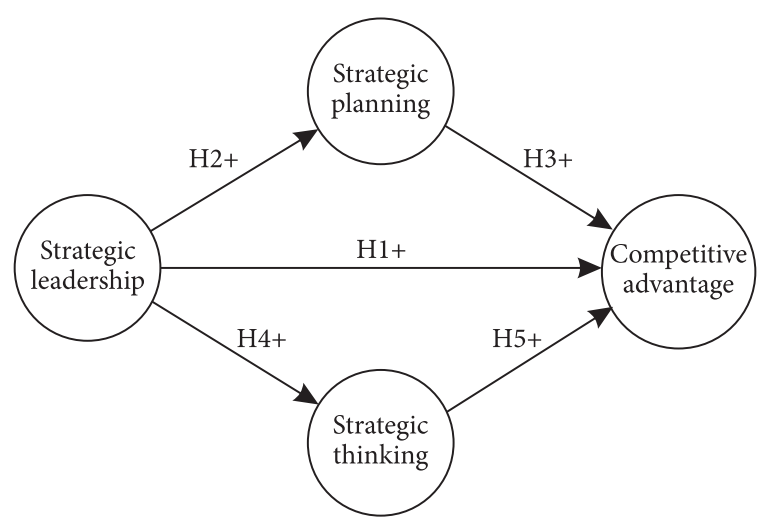

Figure 1. The conceptual model of the study

strategic planning, strategic thinking and competitive advantage). The Figure 1 illustrates four presumed effects among variables.

\subsection{Measures' reliability and validity}

Reliability was measured using Cronbach's Alpha. Convergent validity was measured through the average variance extracted (AVE). The results are shown in Table 3.

The results in Table 3 indicated that all factor loadings were greater than .65. According to Cronbach (1951), reliability refers to the extent to which a measurement included a correct set of items that the researcher can accurately depend on to assess a construct. The results demonstrated that Cronbach's alpha coefficients were also greater than 0.70 (ranging from 0.722 to 0.871 ). The overall reliability coefficient of the scale was 0.812 . Additionally, Composite reliability and average variance extracted values were greater than 0.7 (Fornell and Larcker 1981, Farrell 2010).

\subsection{Intraclass correlation (ICC)}

ICC is method that can be used to evaluate inter-rater agreement. It is a method of evaluating inter-rater reliability in case of two or more raters (Kathuria et al. 2010). Following Boyer and Verma (2000), ICC for multiple-items variables was computed on the basis of the aggregate scale via the following formula: $\mathrm{ICC}=(\mathrm{MSB}-\mathrm{MSW}) /(\mathrm{MSB})$, where MSB refers to MS between groups and MSW refers to MS within groups. The results of the aggregate scale used in the current study showed a value of ICC equals to 0.660 . The suggested standard for ICC as stated by Ebel (1951, as cited in Boyer and Verma 2000) was 0.6 or higher.

\subsection{Model fit}

The model fit was assessed using four indices as shown in Table 4: chi-square statistic/degrees of freedom (Chi2/ df), the goodness-of-fit index (GFI), comparative fit index (CFI), the root mean squared error of approximation (RMSEA) and adjusted goodness-of-fit-index (AGFI). 
Table 3. Results of measurement reliability and validity

\begin{tabular}{|c|c|c|c|c|c|}
\hline Indicators & Items & SL & $\mathrm{CA}$ & $\mathrm{CR}$ & AVE \\
\hline \multirow{6}{*}{$\begin{array}{l}\text { Strategic } \\
\text { orientation }\end{array}$} & ITM1 & 0.76 & \multirow{6}{*}{0.844} & \multirow{6}{*}{0.811} & \multirow{6}{*}{0.737} \\
\hline & ITM2 & 0.82 & & & \\
\hline & ITM3 & 0.71 & & & \\
\hline & ITM4 & 0.78 & & & \\
\hline & ITM5 & 0.80 & & & \\
\hline & ITM6 & 0.79 & & & \\
\hline \multirow{4}{*}{$\begin{array}{l}\text { Strategic } \\
\text { execution }\end{array}$} & ITM7 & 0.88 & \multirow{4}{*}{0.799} & \multirow{4}{*}{0.801} & \multirow{4}{*}{0.749} \\
\hline & ITM8 & 0.82 & & & \\
\hline & ITM9 & 0.69 & & & \\
\hline & ITM10 & 0.77 & & & \\
\hline \multirow{4}{*}{$\begin{array}{l}\text { Strategic } \\
\text { alignment }\end{array}$} & ITM11 & 0.94 & \multirow{4}{*}{0.850} & \multirow{4}{*}{0.841} & \multirow{4}{*}{0.712} \\
\hline & ITM12 & 0.73 & & & \\
\hline & ITM13 & 0.84 & & & \\
\hline & ITM14 & 0.89 & & & \\
\hline \multirow{4}{*}{$\begin{array}{l}\text { Strategic flexi- } \\
\text { bility }\end{array}$} & ITM15 & 0.91 & \multirow{4}{*}{0.861} & \multirow{4}{*}{0.871} & \multirow{4}{*}{0.776} \\
\hline & ITM16 & 0.87 & & & \\
\hline & ITM17 & 0.77 & & & \\
\hline & ITM18 & 0.68 & & & \\
\hline \multirow{4}{*}{$\begin{array}{l}\text { Intangible } \\
\text { capital }\end{array}$} & ITM19 & 0.70 & \multirow{4}{*}{0.840} & \multirow{4}{*}{0.722} & \multirow{4}{*}{0.741} \\
\hline & ITM20 & 0.81 & & & \\
\hline & ITM21 & 0.91 & & & \\
\hline & ITM22 & 0.89 & & & \\
\hline \multirow{6}{*}{$\begin{array}{l}\text { Strategic } \\
\text { planning }\end{array}$} & ITM23 & 0.83 & \multirow{6}{*}{0.821} & \multirow{6}{*}{0.800} & \multirow{6}{*}{0.779} \\
\hline & ITM24 & 0.84 & & & \\
\hline & ITM25 & 0.79 & & & \\
\hline & ITM26 & 0.92 & & & \\
\hline & ITM27 & 0.75 & & & \\
\hline & ITM28 & 0.73 & & & \\
\hline \multirow{6}{*}{$\begin{array}{l}\text { Strategic } \\
\text { thinking }\end{array}$} & ITM29 & 0.79 & & & \\
\hline & ITM30 & 0.83 & & & \\
\hline & ITM31 & 0.78 & 0872 & 0.812 & 0753 \\
\hline & ITM32 & 0.70 & & & \\
\hline & ITM33 & 0.65 & & & \\
\hline & ITM34 & 0.70 & & & \\
\hline & ITM35 & 0.77 & & & \\
\hline & ITM36 & 0.72 & & & \\
\hline Competitive & ITM37 & 0.73 & 0889 & 0799 & 0762 \\
\hline advantage & ITM38 & 0.80 & 0.00 & צינוק & 0.172 \\
\hline & ITM39 & 0.78 & & & \\
\hline & ITM40 & 0.72 & & & \\
\hline $\begin{array}{l}\text { SL: standardize } \\
\text { Composite reli }\end{array}$ & $\begin{array}{l}\text { doadin lo } \\
\text { ability, A }\end{array}$ & $\begin{array}{l}\text { CA: } \\
\text { Ave }\end{array}$ & oach & ha, C & \\
\hline
\end{tabular}

Acceptable values of fit as reported by Schermelleh-Engel et al. (2003) can be seen in Table 1. The results indicated that the current model fitted the data well, Chi2/df value was 2.331 which is less than 3 (Hoe 2008), GFI value was 0.951 which is close to the acceptable value of fit, CFI value was 0.958 which is higher than 0.95 , RMSEA value was 0.061 which is greater than 0.05 and less than 0.10 (Hooper et al. 2008, Bhat et al. 2018). Finally, AGFI value was 0.862 which is higher than 0.80 (Stacciarini and Pace 2017)

\section{Data analysis and results}

\subsection{Descriptive statistics and correlation matrix}

Means and standard deviations (SD) in Table 5 showed high levels of strategic leadership ( $M=3.71, S D=0.74)$, strategic planning $((\mathrm{M}=3.74, \mathrm{SD}=0.68)$, strategic thinking $(\mathrm{M}=$ $3.77, \mathrm{SD}=0.80)$ and competitive advantage $(\mathrm{M}=3.80, \mathrm{SD}=$ 0.81 ). Correlation coefficients among research indicators indicated that all indicators were significantly associated; all correlations ranged from 0.30 to 0.43 were significant either at 0.05 or 0.01 .

\section{Hypotheses testing}

The results of the structural equation modeling, as depicted Table 6 and Figure 2, supported all hypotheses supposed in the current study. As expected, it was found that strategic leadership significantly and positively predicted competitive advantage ( $\beta=0.451, \mathrm{p}<0.05)$, strategic planning ( $\beta=$ $0.27, \mathrm{p}<0.05)$, and strategic thinking $(\beta=0.23, \mathrm{p}<0.05)$. strategic planning has a significant and positive impact on competitive advantage $(\beta=0.33, \mathrm{p}<0.05)$, as well as

Table 4. Results of goodness-of-fit indices

\begin{tabular}{|l|l|l|l|}
\hline \multicolumn{1}{|c|}{ Index } & \multicolumn{1}{c|}{ Value } & \multicolumn{1}{c|}{ Acceptable fit } & \multicolumn{1}{c|}{ Result } \\
\hline Chi2/df & 2.331 & $2<\chi 2 / \mathrm{df} \leq 3$ & Supported \\
\hline GFI & 0.951 & $0.95 \leq \mathrm{CFI}<0.97$ & Supported \\
\hline CFI & 0.958 & $0.95 \leq \mathrm{CFI}<0.97$ & Supported \\
\hline RMSEA & 0.061 & $0.05<\mathrm{SRMR} \leq 0.10$ & Supported \\
\hline AGFI & 0.931 & $0.85 \leq \mathrm{AGFI}<0.90$ & Supported \\
\hline
\end{tabular}

Table 5. Descriptive statistics and inter-correlation matrix

\begin{tabular}{|l|c|c|c|c|c|c|}
\hline \multicolumn{1}{|c|}{ Variables } & Mean & SD & 1 & 2 & 3 & 4 \\
\hline 1. Strategic leadership & 3.71 & 0.74 & - & & & \\
\hline 2. Strategic planning & 3.69 & 0.78 & $0.43^{*}$ & - & & \\
\hline $\begin{array}{l}\text { 3. Strategic thinking } \\
\text { 4. competitive advan- } \\
\text { tage }\end{array}$ & 3.65 & 0.70 & $0.33^{* *}$ & $0.30^{* *}$ & - & \\
\hline $\begin{array}{l}\text { * correlation significant at } 0.05 \text { (Tow-tailed), ** correlation } \\
\text { significant at 0.01 (Tow-tailed). }\end{array}$ \\
\hline
\end{tabular}


strategic thinking has a significant and positive impact on competitive advantage $(\beta=0.37, \mathrm{p}<0.05)$. Based on these results, strategic planning was found to play a significant role as a mediator in the effect of strategic leadership on competitive advantage, as well strategic thinking significantly mediated the effect of strategic leadership on competitive advantage. However, the role played by strategic thinking was greater than the same meditational role played by strategic planning in the effect of strategic leadership on competitive advantage.

\section{Discussion and conclusions}

The purpose of this study was to investigate the effects embedded in a model comprised of four constructs: strategic leadership, strategic thinking, strategic planning and competitive advantage. Four hypotheses were postulated: First, strategic leadership was hypothesized to predict competitive advantage, strategic planning and strategic thinking. Second, strategic planning was assumed to predict competitive advantage. Third, strategic thinking was presumed to predict competitive advantage. The results confirmed that strategic leadership was significantly and positively predicted strategic planning, strategic thinking and competitive advantage. Moreover, strategic thinking and strategic planning were significantly and positively predicted competitive advantage. The effect of strategic leadership on competitive advantage was mediated by strategic planning and by strategic thinking. However, the effect of strategic leadership on competitive advantage through strategic thinking was higher than the effect of strategic leadership on competitive advantage through strategic planning.

The results asserted that strategic leadership, as measured by strategic orientation, strategic execution, strategic

Table 6. Results of hypotheses testing

\begin{tabular}{|c|c|c|c|c|c|c|}
\hline \multicolumn{3}{|c|}{ Hypothesis } & \multirow{2}{*}{$\begin{array}{c}\beta \\
0.451\end{array}$} & \multirow{2}{*}{$\begin{array}{c}\text { S.E. } \\
0.101\end{array}$} & \multirow{2}{*}{$\begin{array}{l}\text { C.R. } \\
8.77\end{array}$} & \multirow{2}{*}{$\frac{\mathrm{P}}{* * *}$} \\
\hline $\begin{array}{l}\text { Competitive } \\
\text { advantage }\end{array}$ & $\leftarrow$ & $\begin{array}{l}\text { Strategic } \\
\text { leadership }\end{array}$ & & & & \\
\hline $\begin{array}{l}\text { Strategic } \\
\text { planning }\end{array}$ & $\leftarrow$ & $\begin{array}{l}\text { Strategic } \\
\text { leadership }\end{array}$ & 0.27 & 0.098 & 7.33 & $* * *$ \\
\hline $\begin{array}{l}\text { Strategic } \\
\text { thinking }\end{array}$ & $\leftarrow$ & \begin{tabular}{|l} 
Strategic \\
leadership
\end{tabular} & 0.23 & 0.120 & 6.15 & $* * *$ \\
\hline $\begin{array}{l}\text { Competitive } \\
\text { advantage }\end{array}$ & $\leftarrow$ & $\begin{array}{l}\text { Strategic } \\
\text { planning }\end{array}$ & 0.33 & 0.064 & 7.91 & $* * *$ \\
\hline $\begin{array}{l}\text { Competitive } \\
\text { advantage }\end{array}$ & $\leftarrow$ & $\begin{array}{l}\text { Strategic } \\
\text { thinking }\end{array}$ & 0.37 & 0.074 & 9.11 & $* * *$ \\
\hline \multicolumn{7}{|c|}{$\begin{array}{l}* * * \text { The regression weight for the variable is significantly diffe- } \\
\text { rent from zero at } 0.05 \text { level. }\end{array}$} \\
\hline
\end{tabular}

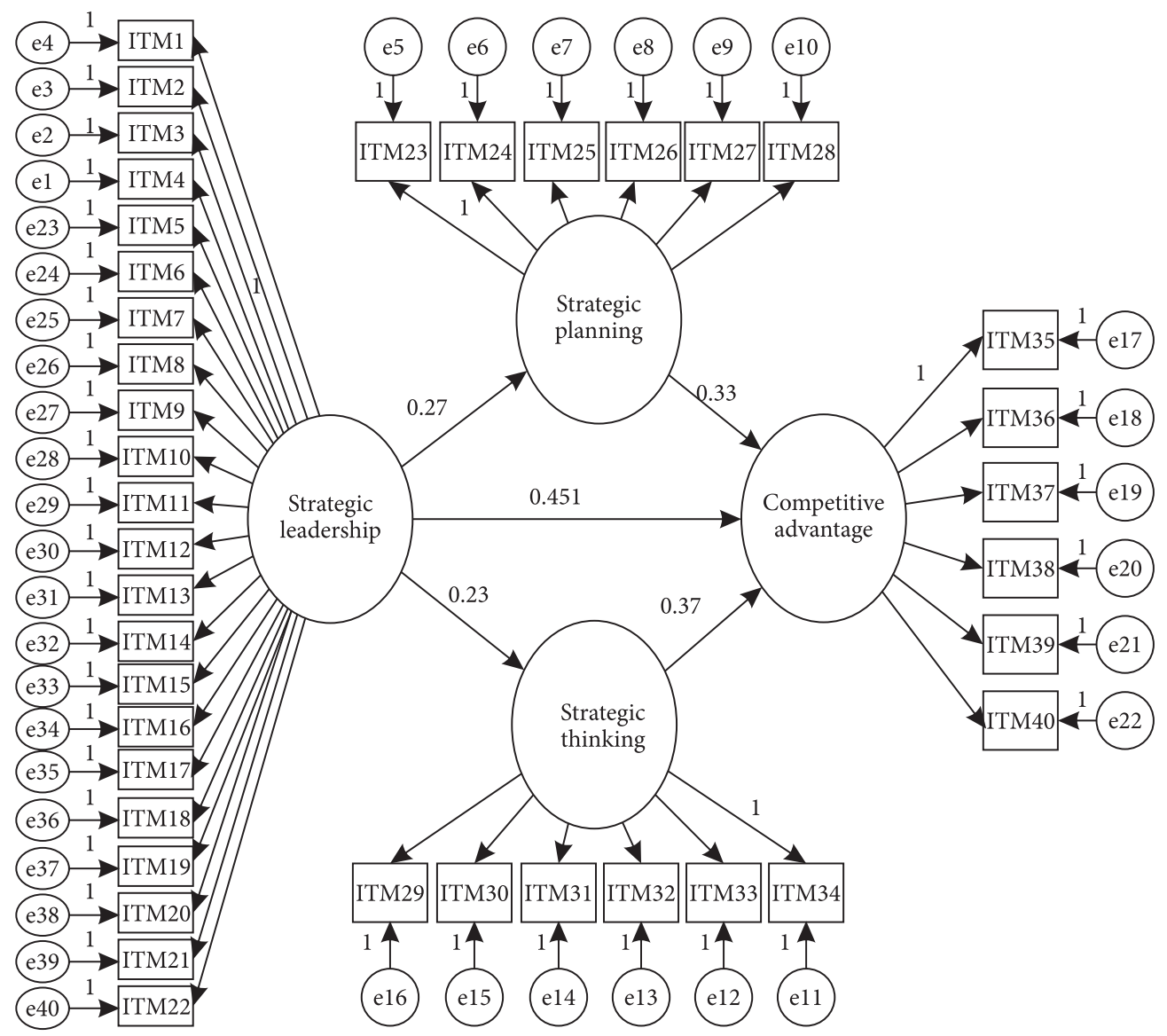

Figure 2. The structural model of the study 
alignment, strategic flexibility and intangible capital, enhanced the organization ability to gain the economic profits that cannot be imitated by other competitors. This result was in agreement with previous studies that showed a positive impact of strategic leadership on competitive advantage (Lado et al. 1992, Combe and Greenley 2004, Zhou et al. 2009, Mahdi and Almsafir 2014, Hili et al. 2017). For Hughes and Beatty (2011), the main job of strategic leadership is to drive the organization toward a long-run success via competitive advantage. On the other hand, strategic leadership was found to significantly predict strategic planning and strategic thinking. This relationship can be explained through the definition of strategic leadership introduced by Hughes and Beatty (2011) in which they stated that strategic leadership is basically related to three key dimensions, which are think, act and influence. Furthermore, both strategic planning and strategic thinking were significantly related to competitive advantage. The results of this study revealed that strategic planning and strategic thinking mediated the effect of strategic leadership on competitive advantage. Mintzberg (1994) described planning as a process of analysis while strategic thinking as a process of synthesis of creativity. In the same line, Betz (2016) argued that strategic thinking is greatly based on intuition which is basically depend on experience that presented by strategic wisdom.

Heracleous (1998) presented three perspectives on the relationship between strategic planning and strategic thinking: First, both strategic planning and strategic thinking are useful for strategic management. Second, strategic thinking is one aspect of strategic planning, since the latter is concerned with facilitate strategic thinking. Third, strategic thinking is more important than strategic planning. Therefore, leaders should turn to strategy thinking. For the current study, the first perspective was adopted in line with the findings that showed a significant meditational role of strategic planning and strategic thinking in the effect of strategic leadership on competitive advantage. In conclusion, strategies are developed via strategic thinking and realized through strategic planning.

\section{Managerial and theoretical implications}

Based on the results, the following managerial and theoretical implications were offered. First, the results that strategic leadership showed a significant effect on competitive advantage clarified that strategic leaders in the top management level play a vital role in strengthening the organization to be able to possess critical competencies that can be imitated. Second, the results that strategic leadership is significantly and positively related to both strategic planning and strategic thinking indicate that the role of leaders in other management levels, i.e., operational and middle levels, is integral to high level leaders. Third, the significant effect of strategic planning and strategic thinking on competitive advantage reveals that the participation process of setting strategic plans in the presence of strategic wisdom inherited from strategic thinking go concurrently to help organizations to gain an exceptional position. Theoretically stated, strategic leadership, strategic planning and strategic thinking were found to be significant predictors of competitive advantage.

\section{Limitations and future research directions}

Participants recruitment was the first limitation experienced in this study. Vera and Crossan (2004) argued that strategic leaders are top management members. For a researcher to collect data on strategic actions via a questionnaire, questions should be administered to strategic leaders at the higher level of the organization. Given the difficulty to approach high level managers in every organization due to their limited time and restricted work schedule, only 87 complete questionnaires were gathered in the first round of data collection. The second round yields 8 questionnaires. Therefore, the population was expanded to cover middle level managers. Boal and Hooijberg (2000) called researchers for taking the surrounding environment of the organization into their consideration when studying strategic leadership, as these environments have become turbulent. They conceptualized strategic leadership in the context of turbulent environments into three dimensions; absorptive capacity, adaptive capacity, and managerial wisdom. Thereby, future research should use these dimensions to measure strategic leadership. Citing DeGeus (1988), Vera and Crossan (2004) in their study on strategic leadership and organizational learning argued that "organizational learning has been proposed as a fundamental strategic process and the only sustainable competitive advantage of the future" (p. 222). organizational learning was not studied in the current study; hence, future research should consider this variable when investigating the relationship between strategic leadership and competitive advantage. Kumar et al. (2011) stimulated the importance of environmental turbulence when studying sources of competitive advantage. Consequently, researchers should take environmental turbulence into their consideration in the relationship between strategic orientations and competitive advantage.

\section{References}

Ahriz S, Benmoussa N, El Yamami A, Mansouri K, Qbadou M (2018) An elaboration of a strategic alignment model of University Information Systems based on SAM Model. Engineering, Technology \& Applied Science Research 8 (1): 2471-2476. 
Avolio B (2007) Promoting more integrative strategies for leadership theory-building. American psychologist 62 (1): 25 . https://doi.org/10.1037/0003-066X.62.1.25

Betz F (2016) Strategic thinking: a comprehensive guide. UK: Emerald Group Publishing Limited. https://doi.org/10.1108/ 9781785604669

Bhat SA, Darzi MA, Parrey SH (2018) Antecedents of customer loyalty in banking sector: a mediational study. Vikalpa 43 (2): 92-105. https://doi.org/10.1177/0256090918774697

Boal K, Hooijberg R (2000) Strategic leadership research: moving on. The Leadership Quarterly 11 (4): 515-549. https://doi. org/10.1016/S1048-9843(00)00057-6

Bourgeois L, Brodwin D (1984) Strategic implementation: five approaches to an elusive phenomenon. Strategic Management Journal 5 (3): 241-264. https://doi.org/10.1002/smj. 4250050305

Boyd BK, Reuning-Elliott E (1998) A measurement model of strategic planning. Strategic Management Journal 19 (2): 181-192. https://doi.org/10.1002/(SICI)1097-0266(199802) 19:2<181::AID-SMJ945>3.0.CO;2-Z

Boyer K, Verma R (2000) Multiple raters in survey-based operations management research: a review and tutorial. Production and Operations Management 9 (2): 128-140. https://doi. org/10.1111/j.1937-5956.2000.tb00329.x

Combe I, Greenley G (2004) Capabilities for strategic flexibility: a cognitive content framework. Emerald Group Publishing Limited.

Cronbach L (1951) Coefficient alpha and the internal structure of tests. Psychometrika 16 (3): 297-334. https://doi.org/10.1007/ BF02310555

Davies, B. (2004) Developing the strategically focused school, School Leadership \& Management 24 (1): 11-27. https://doi. org/10.1080/1363243042000172796

Davies B, Davies B (2004) Strategic leadership. School Leadership \& Management 24 (1): 29-38. https://doi.org/10.1080/13632 43042000172804

Deeboonmee W, Ariratana W (2014) Relationship between strategic leadership and school Effectiveness. Procedia Social and Behavioral Sciences 112: 982-985. https://doi.org/10.1016/j. sbspro.2014.01.1258

DeGeus, A (1988) Planning as learning. Harvard Business Review 66 (2): 70-74.

du Plessis A, Marriott J, Manichith P (2016) Key capabilities for strategic leaders in Lao commercial banking sector to maximize competitive advantage. Journal of Community Positive Practices 16 (1): 56.

Ebener D, Smith F (2015) Strategic planning: an interactive process for leaders. New Jersey: Paulist Press.

Farrell AM (2010) Insufficient discriminant validity: a comment on Bove, Pervan, Beatty, and Shiu (2009). Journal of Business Research 63 (3): 324-327. https://doi.org/10.1016/j.jbusres. 2009.05.003

Fornell C, Larcker D (1981) Evaluating structural equation models with unobservable variables and measurement error. Journal of Marketing Research 18 (1): 39-50. https://doi.org/ $10.2307 / 3151312$

Gratton L, Truss C (2003) The three-dimensional people strategy: putting human resources policies into action. The Academy of
Management Executive 17 (3): 74-86. https://doi.org/10.5465/ ame.2003.10954760

Grawe S, Chen H, Daugherty P (2009) The relationship between strategic orientation, service innovation, and performance. International Journal of Physical Distribution \& Logistics Management 39 (4): 282-300. https://doi. org/10.1108/09600030910962249

Halal W, Taylor K (1999) Twenty-first century economics: perspectives of socioeconomics for a changing world. New York, NY: St Martin's Press.

Heracleous L (1998) Strategic thinking or strategic planning? Long Range Planning 31 (3): 481-487. https://doi. org/10.1016/S0024-6301(98)80015-0

Hili P, Gani M, Hamzah N, Rahman Z (2017) Effect of human capital and leadership on institutions performance and competitive advantages. International Journal of Management \& Social Sciences 7 (3): 479-488. https://doi.org/10.21013/ jmss.v7.n3.p9

Hitt M, Duane R (2002) The essence of strategic leadership: managing human and social capital. Journal of Leadership \& Organizational Studies 9 (1): 3-14. https://doi.org/10.1177/ 107179190200900101

Hitt M, Duane R (2002) The essence of strategic leadership: managing human and social capital. Journal of Leadership \& Organizational Studies 9 (1): 3-14. https://doi.org/10.1177/ 107179190200900101

Hitt M, Keats B, DeMarie S (1998) Navigating in the new competitive landscape: building strategic flexibility and competitive advantage in the 21 st century. The academy of Management Executive 12 (4): 22-42. https://doi.org/10.5465/ ame.1998.1333922

Hoe SL (2008) Issues and procedures in adopting structural equation modeling technique. Journal of applied quantitative methods 3 (1): 76-83.

Hooper D, Coughlan J, Mullen M (2008) Structural equation modelling: guidelines for determining model fit. Electronic Journal of Business Research Methods 6 (1): 53-60.

Hoskisson R, Hitt M, Ireland D, Harrison J (2012) Competing for advantage. UK: Cengage Learning.

Hughes R, Beatty K (2011) Becoming a strategic leader: your role in your organization's enduring success. S.F.: Jossy-Bass, Wiley \& Sons, Inc.

Johnson J, Lee RP, Saini A, Grohmann B (2003) Market-focused strategic flexibility: conceptual advances and an integrative model. Journal of the Academy of Marketing Science 31 (1): 74-89. https://doi.org/10.1177/0092070302238603

Julian O (2013) Relationship between strategic planning and organization's performance in non-governmental organizations (NGOs): a case of ACTIONAID, Kenya. Master research, University of Nairobi, Kenya.

Kathuria R, Partovi F, Greenhaus J (2010) Leadership practices, competitive priorities, and manufacturing group performance. International Journal of Operations \& Production Management 30 (10): 1080-1105. https://doi.org/10.1108/ 01443571011082535

Kumar V, Jones E, Venkatesan R, Leone R (2011) Is market orientation a source of sustainable competitive advantage or simply the cost of competing? Journal of Marketing 75 (1): 16-30. https://doi.org/10.1509/jmkg.75.1.16 
Lado A, Boyd N, Wright P (1992) A competency-based model of sustainable competitive advantage: toward a conceptual integration. Journal of Management 18 (1): 77-91. https:// doi.org/10.1177/014920639201800106

Mahdi O, Almsafir M (2014) The role of strategic leadership in building sustainable competitive advantage in the academic environment. Procedia-Social and Behavioral Sciences 129: 289-296. https://doi.org/10.1016/j.sbspro.2014.03.679

Mintzberg H (1994) The fall and rise of strategic planning. Harvard business review 72 (1): 107-114.

Nadkarni S, Herrmann P (2010) CEO personality, strategic flexibility, and firm performance: the case of the Indian business process outsourcing industry. Academy of Management Journal 53 (5): 1050-1073. https://doi.org/10.5465/ amj.2010.54533196

Podolny J, Khurana R, Hill-Popper M (2005) Revisiting the meaning of leadership. In: Staw B, Kramer R (Eds) Research in Organizational Behavior. Greenwich, CT: JAI Press, 1-36.

Rush S (2011) The leadership in actions series: on strategic leadership. CCL Press: Center for Creative Leadership.

Schermelleh-Engel K, Moosbrugger H, Müller H (2003) Evaluating the fit of structural equation models: tests of significance and descriptive goodness-of-fit measures. Methods of psychological research online 8 (2): 23-74.
Shimizu K, Hitt M (2004) Strategic flexibility: organizational preparedness to reverse ineffective strategic decisions. The Academy of Management Executive 18 (4): 44-59.

Steiner G (2010) Strategic planning: what every managers should know. The Free Press, Simon and Schuster Inc.

Stacciarini TSG, Pace AE (2017) Confirmatory factor analysis of the Appraisal of Self-Care Agency Scale - Revised. The Revista Latino-Americana de Enfermagem 25. https://doi. org/10.1590/1518-8345.1378.2856

Vera D, Crossan M (2004) Strategic leadership and organizational learning. Academy of Management Review 29 (2): 222-240. https://doi.org/10.5465/amr.2004.12736080

Zahra S, Hayton C, Neubaum D, Dibrell C, Craig J (2008) Culture of family commitment and strategic flexibility: the moderating effect of stewardship. Entrepreneurship Theory and Practice 32 (6): 1035-1054. https://doi.org/10.1111/j.1540-6520. 2008.00271.x

Zhou K, Brown J, Dev C (2009) Market orientation, competitive advantage, and performance: a demand-based perspective. Journal of business research 62 (11): 1063-1070. https:// doi.org/10.1016/j.jbusres.2008.10.001 